\title{
The association of the Clock 3111 T/C SNP with lipids and lipoproteins including small dense low-density lipoprotein: results from the Mima study
}

\author{
Kokoro Tsuzaki ${ }^{1}$, Kazuhiko Kotani ${ }^{1}$, Yoshiko Sano ${ }^{1}$, Shinji Fujiwara' ${ }^{2}$,Kaoru Takahashi', Naoki Sakane ${ }^{1 *}$
}

\begin{abstract}
Background: The clock molecule plays major roles in circadian rhythmicity and regulating lipid and glucose metabolism in peripheral organs. Disruption of the circadian rhythm can lead to cardiometabolic disorders. The existence of small dense low-density lipoprotein (sdLDL) in the circulation, an abnormality of lipid metabolism, in part associated with lifestyle, is also one of risk parameters for cardiometabolic disorders. The $3111 \mathrm{~T} / \mathrm{C}$ single nucleotide polymorphism (SNP) of the Clock gene has been reported to be associated with lifestyle including morning/evening preference. We investigated whether the Clock 3111 T/C SNP may affect lipids and lipoproteins including sdLDL.

Methods: In 365 community-dwelling subjects (170 men and 195 women, mean age $63 \pm 14$ years), the 3111 T/C SNP was genotyped using a fluorescent allele-specific DNA primer assay system. The levels of sdLDL were measured with the electrophoretic separation of lipoproteins employing the Lipoprint system.

Results: The frequency of the Clock $3111 \mathrm{C}$ allele was 0.14 . The area of sdLDL did not differ between the subjects with obesity and those without. In carriers of $T / T$ homozygotes, the area of sdLDL was significantly higher compared with carriers of the $C$ allele $(T / C$ or $C / C)(1.7 \pm 3.4$ vs. $0.8 \pm 1.9 \% ; p<0.05)$. A multiple regression analysis showed that the area of sdLDL was significantly and negatively correlated with the Clock 3111 T/C SNP $\beta=-0.114$, $p<0.05)$, independently of age, sex, body mass index, and exercise habits.
\end{abstract}

Conclusion: Our findings indicated that the Clock 3111 T/C SNP might be associated with the existence of sdLDL.

\section{Background}

Sleep can be interrelated with various lifestyle and genetic factors. The sleep-wake cycle is generated through circadian rhythmicity and homeostasis [1,2]. In mammals, physiological processes show approximate 24hour rhythms [3] derived by the clock molecules controlled not only by the master circadian clock in the suprachiasmatic nucleus ( $\mathrm{SCN}$ ) [4-6] but also by peripheral clocks in the liver, muscle, and adipose tissue [7-9]. The clock molecule groups, such as brain and muscle Arnt-like protein-1 (BMAL1) and circadian locomotor

\footnotetext{
* Correspondence: nsakane@kyotolan.hosp.go.jp

'Division of Preventive Medicine and Diabetes Education, Clinical Research Institute for Endocrine and Metabolic Disease, National Hospital Organization Kyoto Medical Center, Kyoto, Japan

Full list of author information is available at the end of the article
}

output cycles protein kaput (CLOCK), also play major roles in circadian rhythmicity and regulating lipid and glucose metabolism in peripheral organs [10]. The human Clock gene located on chromosome $4 \mathrm{q} 12$ has a basic helix-loop-helix domains (for binding DNA). Mutant mice homozygous for Clock exibit an altered diurnal feeding rhythm, developing metabolic syndrome with hyperlipidemia [11], and a reduced amount of time spent asleep both in entrained and free-running conditions [12]. So, disruption of the circadian rhythm leads to metabolic and sleep disorders. A single nucleotide polymorphism (SNP), $3111 \mathrm{~T} / \mathrm{C}$, located in the 3'-flanking region of the Clock gene was reported to be a predictor of diurnal preference in humans [13], although another study reported that the Clock $3111 \mathrm{C}$ allele is 
not associated with eveningness [14]. The $3111 \mathrm{~T} / \mathrm{C}$ SNP influenced sleep and the activity patterns in people affected by bipolar depression, through a possible effect on the stability of mRNA of the Clock gene and the level of Clock protein [15].

Small dense low-density lipoprotein (sdLDL) is produced by abnormal lipid metabolism which leads to increased triglycerides (TG) levels and a difference in clearance between normal and abnormal TG-rich lipoproteins [16]. The existence of sdLDL in the circulation is associated with diabetes mellitus $[17,18]$, diabetic nephropathy [19-21], metabolic syndrome [22], and coronary artery disease (CAD) [23,24]. SdLDL emerges, in part, through lifestyle and genetic factors [25-28]. In this study, we investigate whether the $3111 \mathrm{~T} / \mathrm{C} \mathrm{SNP}$ of the Clock gene may affect lipids and lipoproteins including sdLDL.

\section{Methods}

\section{Study subjects}

All participants were recruited through an annual health check up in the Mima city, Tokushima prefecture in Japan. A total of 365 Japanese community-dwelling subjects, 170 men and 195 women; aged 24 to 88 years, were enrolled in this study. We included subjects who were asymptomatic without any known medical history of coronary heart disease and psychic disease. The study protocol was approved by the Ethics committee of National Hospital Organization Kyoto Medical Center. All the subjects signed an informed consent form after being fully informed about all aspects of the study before enrolling. After an overnight fast, body weight and height were measured using a body fat analyzer (OMRON. Co. Ltd., Osaka, Japan). The body mass index (BMI) was calculated as weight divided by squared height $\left(\mathrm{kg} / \mathrm{m}^{2}\right)$. The blood pressure was measured threetimes at 10-minute intervals using a mercury sphygmomanometer. Venous blood samples were then drawn for blood tests. Blood glucose was measured by the hexokinase method (SHINO-TEST Corporation, Tokyo, Japan), and serum insulin was assayed by chemiluminescent immunoassay (Bayermedical.Co., Ltd., Tokyo, Japan). Serum total cholesterol (Wako Pure Chemical Industries, Ltd., Tokyo, Japan), high density lipoprotein (HDL)-cholesterol, and triglyceride (DAIICHI PURE CHEMICALS Co., Ltd., Tokyo, Japan) were determined by the enzymatic methods. Homeostasis model assessment of insulin resistance (HOMA-IR) was calculated according to a previous study [29]. Medical histories and lifestyle factors (exercise habits [none or done], sleeping time, skipping breakfast and smoking habits) were confirmed by a self-reported questionnaire and medical professionals' interview.

\section{Measurement of the area of sdLDL}

The area of sdLDL was measured with the Lipoprint ${ }^{\mathrm{m}}$ system (Quantimetrix Inc., Redondo Beach, CA) [30]. Briefly, $25 \mu \mathrm{L}$ of serum sample and $200 \mu \mathrm{L}$ of loading gel were applied to a $3.3 \%$ polyacrylamide gel tube and mixed well several times. Next, these samples were photopolymerized at room temperature for $30 \mathrm{~min}$ and then electrophoresed for $65 \mathrm{~min}$ ( $3 \mathrm{~mA} /$ gel tube). After the electrophoresis, a densitometric scanning was done with a ScanMaker i900 (MICROTEK Co., Carson, CA) and the lipoprotein subfractions were calculated with an iMac personal computer (Apple Computer Inc., Cupertino, CA). All the LDL subfractions were calculated based on a relative flotation rate (Rf) between the very $\mathrm{LDL}$ fraction as $\mathrm{Rf}=0.0$ and the HDL fraction as $\mathrm{Rf}=$ 1.0. LDL-1 and LDL-2 are defined as large LDL, and LDL-3 to LDL-7 are defined as sdLDL. The area of sdLDL is expressed as a percentage relative to total lipoproteins.

\section{Genetic analysis}

A noninvasive method was implemented for collecting buccal mucosa cells using cytobrushes. After the phenol-extraction procedure, 0.2 to $2 \mu \mathrm{g}$ of DNA was obtained. Genotypes were determined with an intercalater-mediated fluorescent allele-specific DNA primary assay (TOYOBO Co. Ltd., Tsuruga, Japan). The 3111C/ $T$ polymorphic region of Clock ( $r s 1801260)$ was amplified using the polymerase chain reaction with sense (5'AAT ACC AGC CAG CAG GAG GTG ATC-3') and anti-sense (5'-CAA AAA ATA TCC AGG CAC CTA AAA CAC TG-3') primers, and labeled at the $5^{\prime}$ end with Texas red (5'-ATA GGG GCA CAG CCA GTT C3 '). PCR amplifications were performed under the conditions recommended by the enzyme supplier. In brief, a $25-\mu \mathrm{L}$ aliquot containing $20 \mathrm{ng}$ of genomic DNA, the reaction buffer supplied, $3.0 \mathrm{mM} \mathrm{MgCl} 2,0.2 \mathrm{mM}$ $\mathrm{dNTP}$, and $1.25 \mathrm{U}$ of rTaq containing anti-Taq high (TOYOBO Co. Ltd., Tsuruga, Japan). Cycling parameters were an initial denaturation at $95^{\circ} \mathrm{C}$ for $5 \mathrm{~min}$ utes, then denaturation at $95^{\circ} \mathrm{C}$ for 30 secconds, annealing at $65^{\circ} \mathrm{C}$ for 30 seconds, and primer extension at $72^{\circ} \mathrm{C}$ for 30 seconds for 40 cycles, and post extension at $72^{\circ} \mathrm{C}$ for 2 minutes in a thermal cycler (ABI9700). Two microliters of reaction mixture containing 10 pmoL of probe and SYBR Green (final concentration $\times$ 10000) was added to the PCR products. The mixture was placed in the ABI PRIZM 7700 and the melting temperature was measured. The program for analytical melting was $95^{\circ} \mathrm{C}$ for 30 seconds, then $40^{\circ} \mathrm{C}$ for $1 \mathrm{~min}$ ute, increasing to $80^{\circ} \mathrm{C}$ by 10 minutes. The fluorescence signals were detected at excitation and emission wavelengths of $485 \mathrm{~nm}$ and $612 \mathrm{~nm}$. In this study, all 
samples have checked by two independent investigators. No samples are observed different results.

\section{Statistical analysis}

All statistical analyses were performed with the Statistical Package of Social Science (SPSS for Windows, version 11.0; SPSS Inc., Chicago, IL, USA). Data were expressed as means $\pm \mathrm{SD}$. The present study was designed to detect a difference in means equivalent to $1 \%$ of sdLDL with a SD of $3 \%$. Thus, the sample size required was 286 with an error of $5 \%$, with $80 \%$ power (beta $=20 \%$ ) at the two-tailed 5\% significance level. The differences in values between groups were estimated by using the Student's unpaired $t$-test and $\chi 2$-test. A stepwise multiple regression analysis controlled for measured parameters including the Clock $3111 \mathrm{~T} / \mathrm{C}$ SNP was performed to explore the correlated factors with the area of sdLDL. $\mathrm{P}<0.05$ was accepted as statistically significant.

\section{Results}

Table 1 shows the distribution of the 3111 T/C SNP. The sex difference in the frequency was not observed
Table 2 A stepwise multiple regression analysis for small dense low-density lipoprotein

\begin{tabular}{llll}
\hline Independent variables & \multicolumn{2}{l}{$\begin{array}{l}\text { Regression coefficient (95\% } \\
\mathbf{C l} * \text { ) }\end{array}$} & $\begin{array}{l}\mathbf{P} \\
\text { value }\end{array}$ \\
\hline $\begin{array}{l}\text { Fasting plasma glucose }(\mathrm{mg} / \\
\mathrm{dL})\end{array}$ & 0.013 & (from [0.003] to [0.024]) & 0.015 \\
Sex & & & \\
Clock 3111 T/C SNP a & 0.774 & (from [0.118] to [1.431]) & 0.021 \\
& $-0.838 \quad($ from [-1.598] to & 0.031 \\
& & $[-0.077])$ & \\
\hline
\end{tabular}

* $\mathrm{Cl}$ indicates coefficient interval.

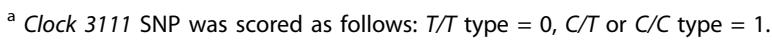

(data not shown). The frequency of the $C$ allele was 0.14, with 277 (75.9\%) of subjects $T / T$ homozygotes, 77 (21.1\%) $T / C$ heterozygotes, and 11 (3.0\%) C/C homozygotes. No significant deviation from Hardy-Weinberg equilibrium was observed.

The physical characteristics and blood test results of the subjects are listed in Table 2 . There were no significant differences between carriers of the $C$ allele $(T / C$ or $C / C)$ and $T / T$ homozygotes in gender distribution, age, BMI, systolic blood pressure, diastolic blood pressure, fasting plasma glucose, fasting serum insulin, HOMA-IR, TG, or total cholesterol and HDL-cholesterol levels. Moreover,

Table 1 Clinical and biological characteristics of subjects according to SNP of the Clock gene

\begin{tabular}{|c|c|c|c|c|c|c|}
\hline Parameters & $\mathrm{T} / \mathrm{T}$ & $\mathrm{T} / \mathrm{C}$ & $\mathrm{C} / \mathrm{C}$ & $\mathrm{T} / \mathrm{T}+\mathrm{T} / \mathrm{C}$ & $\mathrm{T} / \mathrm{C}+\mathrm{C} / \mathrm{C}$ & $P$ value \\
\hline Number & 277 & 77 & 11 & 354 & 88 & \\
\hline Age (years) & $64 \pm 14$ & $65 \pm 13$ & $61 \pm 17$ & $64 \pm 14$ & $65 \pm 14$ & 0.559 \\
\hline Sex (men/women) & $132 / 145$ & $31 / 46$ & $7 / 4$ & $163 / 191$ & $38 / 50$ & 0.464 \\
\hline Skipping breakfast (\%) & 5 & 9 & 0 & 6 & 8 & 0.390 \\
\hline Smoking (current, \%) & 14 & 25 & 27 & 26 & 16 & 0.249 \\
\hline Exercise habit (none/done, \%) & $72 / 18$ & $70 / 30$ & $54 / 46$ & $71 / 29$ & $68 / 32$ & 0.061 \\
\hline \multicolumn{7}{|l|}{ Sleeping time $(\%)^{a}$} \\
\hline$<6$ hours & 21.2 & 19.5 & 27.3 & 20.9 & 20.4 & \\
\hline 6 hours & 20.9 & 10.4 & 0 & 18.6 & 9.1 & \\
\hline 7 hours & 25.3 & 31.1 & 27.3 & 26.6 & 30.7 & 0.090 \\
\hline 8 hours & 24.2 & 33.8 & 27.3 & 26.3 & 33.0 & \\
\hline$\geq 9$ hours & 8.4 & 5.2 & 18.1 & 7.7 & 6.8 & \\
\hline Body mass index $\left(\mathrm{kg} / \mathrm{m}^{2}\right)$ & $24.0 \pm 3.0$ & $23.6 \pm 3.3$ & $25.8 \pm 4.4$ & $23.9 \pm 3.1$ & $23.9 \pm 3.5$ & 0.061 \\
\hline Systolic blood pressure (mmHg) & $137 \pm 19$ & $134 \pm 20$ & $134 \pm 21$ & $136 \pm 19$ & $134 \pm 20$ & 0.228 \\
\hline Diastolic blood pressure $(\mathrm{mmHg})$ & $76 \pm 12$ & $76 \pm 11$ & $73 \pm 15$ & $76 \pm 12$ & $76 \pm 11$ & 0.735 \\
\hline Fasting plasma glucose (mmol/L) & $5.7 \pm 1.7$ & $5.5 \pm 1.9$ & $5.9 \pm 1.7$ & $5.7 \pm 1.7$ & $5.6 \pm 1.9$ & 0.578 \\
\hline Fasting serum insulin (pmol/L) & $47 \pm 51$ & $40 \pm 29$ & $35 \pm 16$ & $46 \pm 47$ & $40 \pm 27$ & 0.193 \\
\hline HOMA-IR & $2.1 \pm 2.9$ & $1.8 \pm 2.6$ & $1.5 \pm 0.7$ & $2.1 \pm 2.9$ & $1.8 \pm 2.5$ & 0.331 \\
\hline Triglycerides (mmol/L) & $1.13 \pm 0.58$ & $1.10 \pm 0.51$ & $1.00 \pm 0.25$ & $1.12 \pm 0.57$ & $1.09 \pm 0.49$ & 0.580 \\
\hline Total cholesterol (mmol/L) & $4.84 \pm 0.93$ & $4.78 \pm 0.88$ & $4.29 \pm 0.83$ & $4.84 \pm 0.91$ & $4.73 \pm 0.88$ & 0.335 \\
\hline HDL-cholesterol (mmol/L) & $1.42 \pm 0.41$ & $1.40 \pm 0.36$ & $1.40 \pm 0.39$ & $1.42 \pm 0.39$ & $1.42 \pm 0.36$ & 0.875 \\
\hline Small dense LDL (\%) & $1.7 \pm 3.4$ & $0.9 \pm 2.0$ & $0.3 \pm 0.7$ & $1.6 \pm 3.2$ & $0.8 \pm 1.9$ & 0.020 \\
\hline
\end{tabular}

Data are means \pm SD.

HOMA-IR, homeostasis model assessment of insulin resistance; HDL, high-density lipoprotein; LDL, low-density lipoprotein.

$\mathrm{P}$ values in a comparison between subjects with $T / T$ genotype and those with $T / C$ or $C / C$ (by using Student's unpaired $t$-test and $\chi 2$-test).

In another model $(T / T+T / C$ vs. $C / C$ ), there were no significant differences in various traits (by using Student's unpaired $t$-test and $\chi 2$-test).

a Four subjects with $T / T$ genotype had no answer. 
the area of sdLDL was significantly higher in the $T / T$ homozygotes $(1.7 \pm 3.4$ vs. $0.8 \pm 1.9 \%)$. There was no difference in the area of sdLDL between subjects with and without obesity (as BMI of more than $25 \mathrm{~kg} / \mathrm{m}^{2}$ ).

In the questionnaire on lifestyle, there was no significant difference in sleeping time between carriers and non-carriers of the $C$ allele (Table 2). Moreover, a stepwise multiple regression analysis for the area of sdLDL revealed a significant, negative, and independent association of the Clock 3111 T/C SNP $(\beta=-0.114, \mathrm{p}=0.031)$ (Table 3).

\section{Discussion}

The present study is the first to demonstrate an association between the Clock $3111 \mathrm{~T} / \mathrm{C}$ SNP and sdLDL in the circulation among community-dwelling people. The most important finding is that the Clock $3111 \mathrm{~T} / \mathrm{T}$ homozygous form might increase the area of sdLDL, independently of potential confounding factors. The mechanism by which the clock molecule and the variation in its gene could be associated with sdLDL remain to be elucidated. The Clock mutant mouse has altered feeding patterns accompanied by the development of obesity and elevated TG, glucose and leptin levels [11], and mutations in Clock and Bmal influence the diurnal variation in TG and glucose concentrations [31]. The Clock mutant mice is also both hyperphageic and obese, and exhibits abnormalities in circulating levels of glucose, lipids, and hormones/adipokines, consistent with a cardiometabolic syndrome phenotype [32]. It was reported, however, that the $3111 \mathrm{~T} / \mathrm{C}$ SNP does not alter the amino acid sequence of the clock protein because $3111 \mathrm{~T} / \mathrm{C}$ SNP locates in the 3'-flanking region of the Clock gene. Therefore, we speculate that the 3111 $T / C$ SNP may affect Clock mRNA level, helping to alter clock protein levels and thereby disturbing other clock molecules' network and circadian rhythmicity. The 3111 $T / C$ SNP has been associated with sleep disruptuin in humans in many studies [13,16,33-38] but not all [39]. Further examination is needed to clarify the mechanism underlying the association between the $3111 \mathrm{~T} / \mathrm{C}$ SNP and sdLDL.

There are several limitations to our study. First, no assessment of sleep patterns (sleep onset time, wake time, and daytime sleepiness) was performed, although there was no significant difference in the prevalence of skipping breakfast and sleeping time. Second, only one SNP was examined. It has been reported that the haplotypes of rs1554483G and rs4864548A are associated with a 1.8-fold increase in the risk of overweightness or obesity [40]. So, we would need to consider more studies on the association between $3111 \mathrm{~T} / \mathrm{C}$ tag and other variants. Third, considering the small sample size in our study, we need to investigate the replication in independent cohorts to confirm our observed association. In the light of our findings, it will be important to further establish the effects of the $3111 T / C$ SNP on gene regulation.

\section{Conclusion}

In conclusion, our findings indicate the $3111 T / C$ SNP of the Clock gene might modify the existence of sdLDL in the circulation. Understanding the mechanisms underpinning the relationship between the environment, our circadian rhythms, and dyslipidemia in the development of cardiovascular disease will provide important pathways for both prevention and management of these conditions.

\section{List of abbreviations}

LDL: low-density lipoprotein; sdLDL: small dense LDL; TG: triglycerides; HDL: high-density lipoprotein; SNP: single nucleotide polymorphism; Clock: circadian locomotor output cycles protein kaput; BMAL1: brain and muscle Arnt-like protein 1; BMI: body mass index; CAD: coronary artery disease; HOMA-IR: homeostasis model assessment of insulin resistance.

\section{Acknowledgements}

This work was supported by a Grant-in-Aid for the Ministry of Health, Welfare, and Labour of Japan, by the foundation for Development of the Community in Japan, and in part, by a grant for Kao Research Council for the Study of Health Science.

\section{Author details}

${ }^{1}$ Division of Preventive Medicine and Diabetes Education, Clinical Research Institute for Endocrine and Metabolic Disease, National Hospital Organization Kyoto Medical Center, Kyoto, Japan. ${ }^{2}$ Mima City National Health Insurance Koyadaira Clinic, Tokushima, Japan.

\section{Authors' contributions}

SF has been the project's reader; KT, KK, YS, SF, and NS have participated in critical revision of this manuscript; KT has performed in the statistical analysis; All authors have read and approved the final version of this manuscript.

\section{Competing interests}

The authors declare that they have no competing interests.

Received: 1 June 2010 Accepted: 21 October 2010 Published: 21 October 2010

\section{References}

1. Borbely AA: A two process model of sleep regulation. Hum Neurobiol 1982, 1:195-204.

2. Daan S, Beersma DG, Borbey AA: Timing of human sleep: recovery process gated by circadian pacemaker. Am J Physiol 1984, 246:R161-183.

3. Gachon F, Nagoshi E, Brown SA, Ripperger J: The mammalian circadian timing system: from gene expression to physiology. Chtomosoma 2004, 113:103-112.

4. King DP, Takahashi JS: Molecular genetics of circadian rhythms in mammals. Annu Rev Neurosci 2000, 23:713-742.

5. Wager-Smith K, Kay SA: Circadian rhythm genetics: from files to mice to humans. Nat Genet 2000, 26:23-27.

6. Schibler U, Sassone-Corsi P: A web of circadian pacemakers. Cell 2002, 111:919-922 
7. Lowrey PL, Takahashi JS: Mammalian circadian biology: elucidating genome-wide levels of temporal organization. Annu Rev Genomics Hum Genet 2004, 5:407-441.

8. Balsalobre A: Clock genes in mammalian peripheral tissues. Cell Tissue Res 2002, 309:193-199.

9. Lamia KA, Storch KF, Weitz CJ: Physiological significance of a peripheral tissue circadian clock. Proc Natl Acad Sci 2008, 105:15172-15177.

10. Yang $X$, Downes $M, Y u R T$, et al: Nuclear receptor expression links the circadian clock to metabolism. Cell 2006, 126:801-810.

11. Turek FW, Joshu C, Kohsaka A, et al: Obesity and metabolic syndrome in circadian Clock mutan mice. Science 2005, 308:1043-1045.

12. Viterna MH, King DP, Chang AM, Kornhauser JM, Lowrey PL, AcDonald JD, Dove WF, Pinto LH, Turkey FW: Mutagenesis and mapping of a mouse gene, clock, essential for circadian behavior. Science 1994, 264:6386-6391.

13. Katzenberg D, Young T, Finn L, Lin L, King DP, Takahashi JS, Mignot E: A CLOCK polymorphism associated with human diurnal preference. Sleep 1998, 21:569-576.

14. Robilliard DL, Archer SN, Arendt J, Lockley SW, Hack LM, English J, Leger D, Smits MG, Williams A, Skene DJ, Von Schantz M: The 3111 Clock gene polymorphism is not associated with sleep and circadian rhythmicity in phenotypically characterized human subjects. J Sleep Res 2002, 11:305-312.

15. Iwase $T$, Kajimura $N$, Uchiyama M, Ebisawa $T$, Yoshimura $K$, Kamai $Y$, et al: Mutation screening of the human Clock gene in circadian rhythm sleep disorders. Psychiatry Res 2002, 15:121-128.

16. Griffin B, et al: Metabolism of VLDL and LDL subclasses. Curr Opin Lipidol 1994, 5:200-206

17. Haffner SM, Mykkanen L, Stern MP, Paidi M, Howard BV: Greater effect of diabetes on LDL size in women than in men. Diabetes Care 1994, 10:1164-1171.

18. Singh AT, Rainwater DL, Haffner SM, VandeBerg JL, Shelledy WR, Moore PH Jr, Dyer TD: Effect of diabetes on lipoprotein size. Arterioscler Thromb Vasc Biol 1995, 15:1805-1811.

19. Yoshino G, Hirano T, Kazumi T: Atherogenic lipoproteins and diabetes mellitus. J Diabetes Complications 2002, 16:29-34

20. Matsui J, Tamasawa N, Tanabe J, Kasai N, Murakami H, Yamato K, Guan J, Suda T: LDL particle size and lipid composition are risk factors for microalbuminuria in normotensive and normocholesterolemic patients with type 2 diabetes. Diabetes Res Clin Pract 2004, 66:229-236.

21. Jenkins AJ, Rowley KG, Lyons TJ, Best JD, Hill MA, Klein RL: Lipoproteins and diabetic microvascular complications. Curr Pharm Des 2004, 10:3395-418, Review.

22. Gentile M, Panico S, Jossa F, Mattiello A, Ubaldi S, Marotta G, Pauciullo P, Rubba P: Postprandial lipaemia, metabolic syndrome and LDL particle size in urbanized South African blacks with and without coronary artery disease. QJM 2008, 101:111-119.

23. Crouse JR, Parks JS, Schey HM, Kahl FR: Studies of low density lipoprotein molecular weight in human beings with coronary artery disease. J Lipid Res 1985, 26:566-574

24. Austin MA, Breslow JL, Hennekens CH, Buring JE, Willett WC, Krauss RM: Low-density lipoprotein subclass patterns and risk of myocardial infarction. JAMA 1988, 260:1917-1920.

25. Griffin MD, Sanders TA, Davies IG, Morgan LM, Millward DJ, Lewis F, Slaughter S, Cooper JA, Miller GJ, Griffin BA: Effects of altering the ratio of dietary n-6 to n-3 fatty acids on insulin sensitivity, lipoprotein size, and postprandial lipemia in men and postmenopausal women aged $45-70 \mathrm{y}$ : the OPTILIP Study. Am J Clin Nutr 2006, 84:1290-1298.

26. Kawano M, Shono N, Yoshimura T, Yamaguchi M, Hirano T, Hisatomi A: Improved cardio-respiratory fitness correlates with changes in the number and size of small dense LDL: randomized controlled trial with exercise training and dietary instruction. Intern Med 2009, 48:25-32.

27. Tsuzaki K, Kotani K, Fujiwara S, Sano Y, Matsuoka Y, Domichi M, Hamada T, Shimatsu A, Sakane N: The Trp64Arg polymorphism of beta3-adrenergic receptor gene is associated with increased small dense low-density lipoprotein in a rural Japanese population: the Mima study. Metabolism 2007, 56:1689-1693.

28. Hamada T, Kotani K, Fujiwara S, Sano Y, Domichi M, Tsuzaki K, Sakane N: The common $-55 \mathrm{C} / \mathrm{T}$ polymorphism in the promoter region of the uncoupling protein 3 gene reduces prevalence of obesity and elevates serum high-density lipoprotein cholesterol levels in the general Japanese population. Metabolism 2008, 57:410-415.
29. Matthews DR, Hosker JP, Rudenski AS, Naylor BA, Treacher DF, Turner RC: Homeostasis model assessment: insulin resistance and beta-cell function from fasting plasma glucose and insulin concentrations in man. Diabetologia 1985, 28:412-419.

30. Son JE, Lee W, Min WK, Chun S, Lee YW, Park H: Distribution of lowdensity lipoprotein particle size in healthy Korean adult males. Clin Chem Lab Med 2004, 42:235-237.

31. Rubic RD, McNamara P, Curtis AM, Boston RC, Panda S, Hogenesch JB, Fitzgerald GA: BMAL1 and CLOCK, two essential components of the circadian clock, are involved in glucose homeostasis. PLos Biol 2004, 2 e377.

32. Turek FW, Joshu C, Kohsaka A, Lin E, Ivanova G, McDrmon E, Laposky A Losee-Olson S, Easton A, Jensen DR, Eckel RH, Takahashi JS, Bass J: Obesity and metabolic syndrome in circadian Clock mutant mice. Science 2005, 308:1043-1045

33. Benedetti F, Dallaspezia S, Fulgosi MC, Lorenzi C, Serretti A, Barbini B, Colombo C, Smeraldi E: Actimetric evidence that CLOCK 3111 T/C SNP influences sleep and activity patterns in patients affected by bipolar depression. Am J Med Genet B Neuropsychiatr Genet 2007, 144B:631-635.

34. Benedetti F, Serretti A, Colombo C, Barbini B, Lorenzi C, Campori E, Smeraldi E: Influence of CLOCK gene polymorphism on circadian mood fluctuation and illness recurrence in bipolar depression. Am J Med Gene B Neuropsychiatr Genet 2003, 123B:23-26.

35. Serretti A, Cusin C, Benedetti F, Mandelli L, Pirovano A, Zanardi R, Colombo C, Smeraldi E: Insomnia improvement during antidepressant treatment and CLOCK gene polymorphism. Am J Med Genet $B$ Neuropsychiatr Genet 2005, 137B:36-39.

36. Serretti A, Benedetti F, Mandelli L, Lorenzi C, Pirovano A, Colombo C, Smeraldi E: Genetic dissection of psychopathological symptoms: insomnia in mood disorders and CLOCK gene polymorphism. Am J Med Genet B Neuropsychiatr Genet 2003, 121B:35-38

37. Mishima K, Tozawa T, Satoh K, Saito H, Mishima Y: The 3111 T/C polymorphism of hClock is associated with evening preference and delayed sleep timing in a Japanese sample. Am J Med Genet B Neuropsychiatr Genet 2005, 133B:101-104.

38. Pirovano A, Lorenzi C, Serretin A, Plodia C, Landoni S, Catalano M, Smeraldi E: Two new rare variants in the circadian "clock" gene may influence sleep pattern. Genet Med 2005, 7:455-457.

39. Pedrazzoli M, Louzada FM, Pereira DS, Benedito-Silva AA, Lopez AR, Martynhak BJ, Korczak AL, Koike Bdel V, Barbosa AA, D'Almeida V, Tufik S: Clock polymorphisms and circadian rhythms phenotypes in a sample of the Brazilian population. Chronobiol Int 2007, 24:1-8

40. Sookoian S, Gemma C, Gianotti TF, Burgueño A, Castaño G, Pirola CJ: Genetic variants of Clock transcription factor are associated with individual susceptibility to obesity. Am J Clin Nutr 2008, 87:1606-15.

\section{Pre-publication history}

The pre-publication history for this paper can be accessed here: http://www.biomedcentral.com/1471-2350/11/150/prepub

\section{doi:10.1186/1471-2350-11-150}

Cite this article as: Tsuzaki et al:: The association of the Clock $3111 \mathrm{~T} / \mathrm{C}$ SNP with lipids and lipoproteins including small dense low-density lipoprotein: results from the Mima study. BMC Medical Genetics 2010 $11: 150$

\section{Submit your next manuscript to BioMed Central and take full advantage of:}

- Convenient online submission

- Thorough peer review

- No space constraints or color figure charges

- Immediate publication on acceptance

- Inclusion in PubMed, CAS, Scopus and Google Scholar

- Research which is freely available for redistribution 